\title{
Geobacillus sp., a Thermophilic Soil Bacterium Producing Volatile Antibiotics
}

\section{Authors: Yuhao Ren, Gary Strobel, Joe Sears, and Melina Park}

This is a postprint of an article that originally appeared in Microbial Ecology on January 22, 2010. The final publication is available at Springer via http://dx.doi.org/10.1007/s00248-009-9630-9.

Ren, Y., Strobel, G.A., Sears, J., and Park, M. 2010. Geobacillus sp. a thermophilic bacterium producing volatile antibiotics. Microbial Ecology. 60: 130-136.

Made available through Montana State University's $\underline{\text { ScholarWorks }}$ scholarworks. montana.edu 


\section{Geobacillus sp. a Thermophilic Soil Bacterium Producing Volatile Antibiotics}

Yuhao Ren ${ }^{\mathrm{a}}$, Gary Strobel, ${ }^{\mathrm{a}^{*}}$ Joe Sears ${ }^{\mathrm{b}}$, and Melina Park ${ }^{\mathrm{a}}$

${ }^{a}$ Department of Plant Sciences, Montana State University, Bozeman, Montana, USA, 59717

${ }^{\mathrm{b}}$ Center for Lab Services/RJ Lee Group, 2710 North $20^{\text {th }}$ Ave., Pasco, Washington, USA 99301,

*Corresponding author: Tel. =1 (406) 994 5148; fax (406) 994760

E-mail address: uplgs@montana.edu

Key Words - Soil bacterium, antibiotics, thermal vents, rDNA, thermophile Running Head- Geobacillus VOCs 


\section{Abstract}

Geobacillus, a bacterial genus, is represented by over 25 species of Gram positive isolates from various man made and natural thermophilic areas around the world. An isolate of this genus (M-7) has been acquired from a thermal area near Yellowstone National Park, Montana, and partially characterized. The cells of this organism are globose (ca. $0.5 \mu$ dia.), and they are covered in a matrix-capsule which give rise to elongate multi-celled bacilliform structures (ranging from 3-12 $\mu$ ) as seen by light and atomic force microscopy (AFM), respectively. The organism produces unique petal shaped colonies (undulating margins) on nutrient agar and it has an optimum $\mathrm{pH}$ of 7.0 and an optimum temperature range of $55-65^{\circ} \mathrm{C}$. The partial $16 \mathrm{~S}$ rRNA sequence of this organism has $97 \%$ similarity with Geobacillus stearothermophilus, one of its closest relatives, genetically. However, uniquely among all members of this genus, M-7 produces volatile organic substances (VOCs) that possess potent antibiotic activities. Some of the more notable components of the VOCs are benzaldehyde; acetic acid; butanal, 3-methyl-; butanoic acid, 2-methyl- ; butanoic acid; propanoic acid, 2-methyl- and benzeneacetaldehyde. An exposure of test organisms such as Aspergillus fumigatus, Botrytis cinerea, Verticillium dahliae, Geotrichum candidum produced total inhibition of growth on a $48 \mathrm{hr}$ exposure to M-7 cells ( ca.10 ${ }^{7}$ ) and killing at a $72 \mathrm{hr}$ exposure at higher bacterial cell concentrations. A synthetic mixture of those available volatile compounds, at the ratios occurring in M-7, mimicked the bioactivity of M-7. This work has interesting implications in the role of M-7 to other organisms in its native environment. 


\section{Introduction}

The Yellowstone National Park ecosystem in Wyoming, Idaho and Montana of Northwestern United States is one of the most active thermal areas in the world. It holds promise as a source of novel microorganisms that are adapted for survival under extremely adverse conditions $[3,6,9,11,12]$. It is from this area that Thermus aquaticus was originally isolated and, more recently, a plethora of other microbes [2]. Thus, in this area we began a search for other thermophiles having unusual and biologically interesting properties. One organism, answering the description of a bacilliform bacterium, appeared in our selection process. The organism was genetically unique but seemed to be related to the previously described bacterial genus-Geobacillus $[1,7,10]$. Furthermore, this organism was demonstrated to produce volatile organic compounds (VOCs) [4,5]. Although bacteria, in general, have been described that make volatiles (VOCs) under various conditions of fermentation, none of these are Geobacillus spp. [5]. Furthermore, the VOCs of this organism possessed antimicrobial activity.

Since our isolate appeared to be related to the bacterial genus- Geobacillus, this group belongs to Bacillus genetic group 5 which represents a phenotypically and phylogenetically coherent group of thermophilic bacilli with high levels of partial $16 \mathrm{~S}$ rRNA sequence similarity $(96.5-99.5 \%)$ [1,10]. Generally, these bacteria are rod-shaped Gram-positive bacteria having growth temperature optima ranging from 35 to $78^{\circ} \mathrm{C}$ $[1,10]$. Members of this genus grow aerobically or facultatively anaerobically and are widely distributed in various naturally or artificially induced thermophilic areas such as soils, hot springs, oilfields, hydrothermal vents, hay compost, hot water pipelines, heat exchangers, waste treatment plants, burning coal refuse piles and bioremediation biopiles $[1,7]$. Presently, this genus is represented by over 25 species [1,7]. Thus, this report describes the isolation of Geobacillus sp. isolate M-7 and demonstrates that it, seemingly uniquely, makes bioactive volatile compounds and shows that an artificial mixture of many of the volatiles of this organism mimic the biological effects of the organism itself. 


\section{Materials and Methods}

\section{Collection of samples}

A sample of soil was collected (5/6/08) from the soil in the northern area of the Yellowstone ecosystem at: N 45 05' 461"; W $110^{\circ} 46^{\prime} 573^{\prime \prime}$. Samples were taken from the inner layers of a small hole formed in the soil which was exuding white gases. The soil was grey/green in appearance having a temperature at the time of collection at $55^{\circ} \mathrm{C}$ and a $\mathrm{pH}$ of 6.7. The sample was designated $\mathrm{M}-7$ and was immediately processed the same day as sampling for its microbial content.

\section{Enrichment and isolation}

Enrichment and isolation of aerobic/thermophilic bacteria was carried out on nutrient broth (NB) solution at $55^{\circ} \mathrm{C}$. Pure cultures were obtained by repeated transfers of serial dilution cultures. The purity of the cultures was checked microscopically. A pure colony arising from this sample was designated M-7 and kept on nutrient agar (NA) at $55^{\circ} \mathrm{C}$.

\section{Microscopy}

Bacterial cells, from well developed bacterial suspensions, were observed after Gram staining using a light microscopy. In order to have an idea of the surface structure of the cells of M-7, atomic force microscopy (AFM) was carried out with a Nanoscope IIIa Extended Multimode AFM from Veeco (Santa Barbara, CA) with a J-type scanner using the methods of Suo et al. [15]. Briefly, a 2 week old, $100 \mu \mathrm{L}$ turbid suspension of M-7 in NB medium was brought to room temperature, placed on a freshly cleaved muscovite mica disk, and kept at ambient conditions for 10 min before being rinsed with $100 \mathrm{mM}$ sodium phosphate buffer and then dried with a stream of dry nitrogen. Silicon probes of resonant frequency $200-400 \mathrm{kHz}$ were used (Model TESP, Digital Instruments) and the scan rate was $0.5 \mathrm{~Hz}$.

\section{Physiological characteristics}

The bacterium (M-7) was grown in 100 broth of NB (pH 7.0) in an incubator under varying temperatures. The growth was observed $35^{\circ} \mathrm{C}, 40^{\circ} \mathrm{C}, 45^{\circ} \mathrm{C}, 50^{\circ} \mathrm{C}, 55^{\circ} \mathrm{C}, 60^{\circ} \mathrm{C}$, 
$65^{\circ} \mathrm{C}, 70^{\circ} \mathrm{C}, 75^{\circ} \mathrm{C}$ and $80^{\circ} \mathrm{C}$, respectively. Likewise, the effect of $\mathrm{pH}$ on growth was determined in the $\mathrm{NB}$ medium adjusted to the appropriate $\mathrm{pH}$ with $\mathrm{HCl}$ and $\mathrm{NaOH}$ between 3.0 and 11.0 at $55^{\circ} \mathrm{C}$. Turbidity and plate counting methods were used to determine bacterial growth characteristics.

\section{Phylogenetic analysis}

Bacterial genomic DNA was extracted from cell pellets (after cultivation on nutrient broth for 3 weeks at $65^{\circ} \mathrm{C}$ and it was obtained according to Stöhr et al [12]. The 16S rRNA gene was amplified from isolated DNA using PCR. Each PCR mixture contained:

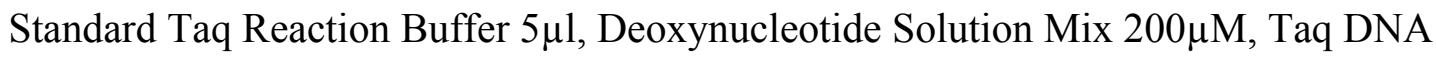
Polymerase 0.2units $/ \mu 1$ (New England Biolab). Isolated DNA $5 \mu \mathrm{g} / \mathrm{mL}$. Bac8f(5'AGAGTTTGATCCTGGCTCAG-3') $0.2 \mu \mathrm{M}$ and Univ1392r (5'ACGGGCGGTGTGTAC-3') $0.2 \mu \mathrm{M}$. The thermal cycler protocol was $95^{\circ} \mathrm{C}$ for $4 \mathrm{~min}$, 34 cycles of $95^{\circ} \mathrm{C}$ for $45 \mathrm{~s}, 54^{\circ} \mathrm{C}$ for $45 \mathrm{~s}, 72^{\circ} \mathrm{C}$ for $75 \mathrm{~s}$, and a final 10 min extension at $72^{\circ} \mathrm{C}$. Negative control reactions (no template) were routinely performed to ensure purity. The PCR products were purified using the Purelink Quick Gel Extraction Kit (Invitrogen corporation). Partial 16S rRNA gene sequences were compared to the GenBank database by using BLAST. The size of 16S rRNA gene used for alignment was 839 nucleotides. The partial DNA sequences were aligned and compared to each other using the Molecular Evolutionary Genetics Analysis (MEGA) software version 3.3.14. A phylogenetic tree was constructed using data from the BLAST search. The sequence was deposited in the Genbank and was assigned the accession number FJ896054.

\section{Comparison with related species and other microbes}

A strain of Geobacillus stearothermophilus ATCC 7953, the closest genetic relative of M-7, was purchased from the American Type Culture Collection (ATCC). It was compared with M-7 relative to colony shape, and with images obtained by AFM as well as its bioactivities. Other microbes used for testing were some common plant pathogens that are usually used in bioassays in this laboratory. They represent a yeast-like fungus, a Phycomycete, and several Fungi Imperfecti obtained from the Montana State University living culture collection. 


\section{Analysis of M-7 gases}

Gases were qualitatively analysed in the air space above cultures of M-7 grown for 21 days at $55{ }^{\circ} \mathrm{C}$ on $100 \mathrm{~mL}$ of $\mathrm{NB}$ in a sealed $250 \mathrm{~mL}$ brown glass bottle. Ultimately, the bacterial suspension was transferred to a bottle having a Teflon-based septum for analysis. First, a baked "Solid Phase Micro Extraction" syringe (Supelco) consisting of $50 / 30$ divinylbenzene/carburen on polydimethylsiloxane on a stable flex fiber (gray) was placed into the bottle containing the bacterial suspension and it was exposed to the vapor phase for $45 \mathrm{~min}$ [13]. The syringe was then inserted into the splitless injection port of a Hewlett Packard 6890 gas chromatograph (GC) containing a $30 \mathrm{~m} \times 0.25 \mathrm{~mm}$ I.D. ZB Wax capillary column with a film thickness of $0.50 \mathrm{~mm}$. The column was temperature programmed as follows: $30^{\circ} \mathrm{C}$ for $2 \mathrm{~min}$ followed to $220^{\circ} \mathrm{C}$ at $5{ }^{\circ} \mathrm{C} / \mathrm{min}$. The carrier gas was ultra high purity Helium (local distributor) and the initial column head pressure was $50 \mathrm{kPa}$. Prior to trapping the volatiles, the fiber was conditioned at $240^{\circ} \mathrm{C}$ for $20 \mathrm{~min}$ under a flow of helium gas. A $30 \mathrm{sec}$ injection time was used to introduce the sample fiber into the GC. The gas chromatograph was interfaced to a Hewlett Packard 5973 mass selective detector (mass spectrometer/MS) operating at unit resolution. The MS was scanned at a rate of 2.5 scans per second over a mass range of 35-360 amu. Data acquisition and data processing were performed on the Hewlett Packard ChemStation software system. Initial identification of the compounds produced by M-7 was made through library comparison using the NIST database. If possible, authentic compounds were obtained from Sigma/Aldrich Chemical Co. and subjected to the identical analysis as a means to confirm compound identity. The names of the organic compounds referred to in this report follow that used in the NIST data base.

\section{Bioassay test for volatile antimicrobials}

A simple bioassay test system was devised that allowed only for an assessment of the biological activity of the VOCs from the bacterium being tested. A glass rod supporting a small plug of foam onto which was placed a piece of agar (potato dextrose agar-PDA) containing hyphae of the test organism was placed into a sterile $10 \mathrm{~mL}$ screw capped vial. 
At the base of the vial was placed the bacterial suspension to be tested (Fig 1). The volatiles produced by the bacteria with antifungal activity were tested for their ability to inhibit/kill test organisms. The NB medium without the M-7 culture was set up as a control. The number of bacterial cells was increased in order to acquire killing of the test organisms. Effectiveness of the M-7 in inhibiting and killing test microbes was recorded as a function of bacterial concentration in the assay tube (Fig.1). The tests were repeated at least three times with comparable results.

The antifungal activities of the artificial mixture and individual components of the M-7 VOCs were tested as previously outlined using some of the same test organisms [13]. Growth of the control assay cultures was ascertained relative to that of the assay cultures in the presence of the bacterial culture and data recoded relative to the behavior of the control. The $\mathrm{IC}_{50} \mathrm{~s}$ (as $\mu \mathrm{l} / \mathrm{ml}$ of air space above the Petri plate) of the artificial mixture of the VOCs were determined using potato dextrose agar (PDA) plates containing microcups having different volumes of the artificial VOC mixture [13]. The mixture was prepared using the proportions (volumes) of individual compounds that appeared during the GC/MS analysis of the M-7 volatiles. The experiments were repeated at least 3 times and the data presented as averages with corresponding standard deviations of the means.

\section{Results and Discussion}

General biology and phylogenetics of Geobacillus sp. M-7

Geobacillus sp. M-7 grew optimally at $\mathrm{pH}$ 6.5-7.0, with a temperature optimum range of $55-65^{\circ} \mathrm{C}$. The partial $16 \mathrm{~S}$ rDNA sequence of M-7 indicated a $97 \%$ similarity to $G$. stearothermophilus - ATCC 7953. The M-7 isolate produced acids and volatile organic compounds (VOCs) with antibiotic activities in the NB. In contrast, $G$. stearothermophilus did not produce VOCs having antibiotic activity. Aqueous glycerol solutions (15\%) have been placed in the MSU microbiological culture collection as culture No.-2366 and held at $-70^{\circ} \mathrm{C}$. Soil from which the organism was originally collected has also been kept at freezer conditions for re-isolation of the organism at the MSU facility. 
On the surface of nutrient agar, M-7 formed roundish, white colonies $1 \mathrm{~mm}$ in diameter. The colonies had irregular margins giving them a rough petal shaped appearance. This is in contrast to G. stearothermophilus, one of the closest genetic relatives of this microbe, whose colonies are white with smooth margins. The cells of M-7 are Gram positive and are globose with a strong-solid matrix. They appear singly, or there may be several arranged in a rod- like manner of varying lengths (Fig. 2). In contrast, other Geobacilli usually appear as a definitive single rod- shaped cells or series of rod- shaped cells aligned in a linear manner $[7,10]$.

The individual cells of M-7 are globose with an irregular shaped matrix (Fig. 3). The surface structure of G. evitos, as examined AFM, revealed an uneven surface but with amorphous non- descript spreading margins represented by matrix material (Fig. 3). In contrast, the surface G. stearothermophilus did not possess these features (data not shown). It appears that M-7 has enough unique features for it to eventually be designated as a novel species of Geobacillus.

\section{Volatile organic compounds with antibiotic activity}

Some bacterial species make VOCs with biological and economic potential [4,5]. Thus, since cultures of M-7 possessed a distinctive odor, it seemed reasonable to ascertain if the VOCs associated with this organism might have biological activity of the type that is so distinctive of certain fungi in the fungal genus -Muscodor $[13,14]$. Thus, it was necessary to devise a biological assay system in which the VOCs being emitted by the bacterial culture could be exposed to the test microbe (Fig.1). Using this simple bioassay technique it was possible to demonstrate that M-7 produced VOCs having relative broad antifungal activities (Table 1). An exposure of test organisms such as Aspergillus fumigatus, Botrytis cinerea, Verticillium dahliae, Geotrichum candidum produced total inhibition of growth on a $48 \mathrm{hr}$ exposure to bacterial cells ( in the range of $10^{7}$ ). In fact, both filamentous fungi and a yeast like- fungus, $G$ candidum, were inhibited by the bacterial VOCs (Table 1). The biological activities were measured as a function of the concentration of the bacterial cells in the medium located at the assay tube. It seemed that A. fumigatus, a human lung pathogen, was one of the more sensitive fungi to the bacterial 
VOCs (Table 1). Also affected at higher concentrations of M-7cells were a series of plant pathogenic fungi (Table 1). Although the test organisms were only $100 \%$ inhibited in their growth under these conditions, when the concentration of bacterial cells was increased by 0.5 to 1 order of magnitude then the death of each of the test organisms was observed at a $72 \mathrm{hr}$ exposure.

\section{The chemical and biological nature of the VOCs of Geobacillus sp. M-7}

A GC/MS analysis of the VOCs of M-7revealed the presence of a variety of aldehydes, alcohols, acids, and other assorted compounds (Table 2). Benzaldehyde, butanoic acid, 2-methyl- , and benzeneacetaldehyde were the major components (16.29, 13.9, and 6.56 in relative areas) of the VOCs of M-7 (Table 2). Those compounds with an asterisk in the table were positively identified based on the acquisition of comparable GC/MS data using authentic compounds. Interestingly, quinoline, 3-methyl-also appeared as one of the VOCs as well as ethanone, 1-(2-aminophenyl)- and 2(3H)furanone, dihydro-4-methyl-. Those compounds (with asterisks) that could be secured from commercial sources were tested individually and in combination for their biological activity using the PDA plate bioassay system for artificial VOC mixtures as described by Strobel et al., 2001[14].

Initially, an artificial mixture of the VOCs was tested at various levels using the microcup assay technique to ascertain the $\mathrm{IC}_{50}$ values on each of the test organisms. The composition of the test liquid contained each of the VOCs made by M-7 at the concentration made by the fungus as ascertained by the relative peak area of GC/MS analysis of the bacterial gases (Table 2). It appeared that Rhizoctonia solani and Sclerotinia sclertiorum possessed the lowest $\mathrm{IC}_{50}$ values and thus seemed to be the most sensitive to the artificial gas mixture. However, these organisms in addition to Aspergillus fumigatus, Pythium ultimum, Trichodema viride, Ceratocystis ulmi and Cercospora beticola required the smallest volume of the VOC mixture to cause $100 \%$ inhibition of fungal growth (Table 3). It appears that there was not a direct correlation between the reaction of the test organisms to the M-7 VOCs and the artificial mixture of VOCs other than Aspergillus fumigatus appeared to be one of the most sensitive organisms to both of these VOC mixes (Tables 1 and 3). This might be related to the fact 
that the entire set of bacterial VOCs were not used in the artificial mixture since they were not available.

Interestingly, when the individual compounds were tested against all assay organisms, consistently, the lowest $\mathrm{IC}_{50} \mathrm{~s}$ of the various compounds tested were exhibited by benzaldehyde followed by butanoic acid and then butanal, 3-methyl- (data not shown). The other volatiles ranged from having little to no activity. Surprising, was the absence of activity in quinoline, 3-methyl- since the quinolines form a base structure for such important antibiotics as the actinomycins [15].

\section{The ecology of Geobacillus sp.M-7}

While M-7 could consistently be isolated from soils in the general area described in this report its presence elsewhere in geothermal areas of the world is an open question. It appears that it is a novel species of Geobacillus and additional efforts are needed to establish this assumption. The VOCs of this organism are totally unlike those produced by various species of Muscodor, thus it appears that there is no single effective combination of volatile organic compounds that have antibiotic activity $(13,14)$. The role of these compounds in the biology of M-7 is even more uncertain. Their production, under natural circumstances, is probably related to the kind and amount of substrates available. Nevertheless, it is tempting to suggest that gas production by this organism in nature plays some role in its successful ability to occupy certain niches by out-competing other organisms.

\section{Acknowledgements}

The authors acknowledge the assistance of NSF grant CBET-0802666 in providing support for this project. Ms. Suzan Strobel constructed the drawing represented in Fig. 1. The Howard Hughes undergraduate research program at MSU supported the summer stipend of Ms. Melina Park who worked on this project. 


\section{References}

1. Abd Rahman RN, Leow TC, Salleh AB, Basri M (2007) Geobacillus zalihae sp. nov., a thermophilic lipolytic bacterium isolated from palm oil mill effluent in Malaysia. BMC Microbiol 10: 70-77.

2. Brock TD (1995) The road to Yellowstone-and beyond. Ann Rev Microbiol 49: 1-28

3. Johnson DB, Okibe N, Roberto FF (2003) Novel thermo-acidophilic bacteria isolated from geothermal sites in Yellowstone National Park: physiological and phylogenetic characteristics. Arch Microbiol 180:60-68

4. Kai M, Effmert U, Berg G, Piechulla B (2007) Volatiles of bacterial antagonists inhibit mycelial growth of the plant pathogen Rhizotonia solani. Arch Microbiol 187 :351360 .

5. Kai M, Haustein M, Molina F, Petri A, Schjolz B, Piechulla B (2009) Bacterial volatiles and their action potential. Appl Microbiol Biotechnol 81: 1001-1012

6. Kozubal M, Macur RE, Korf S, Taylor WP, Ackerman GG, Nagy A, Inskeep WP (2008) Isolation and distribution of a novel non-oxidizing crenarchaeon from acidic geothermal springs in Yellowstone National Park. Appl Environ Microbiol 74: 942949

7.McMullan G, Christie JM, Rahman TJ, Banat IM, Ternan NG, Marchant R (2004) Habitat, applications and genomics of the aerobic, thermophilic genus Geobacillus. Biochem Soc Trans 32:214-7 
8. Mosmann T (1983) Rapid colorimetric assay for cellular growth and survival: application to proliferation and cytotoxicity assays. J Immunol Methods 65: 55-63.

9.Nakagawa S, Shtaih Z, Banta A, Beveridge TJ, Sako Y, Reysenbach AL (2005) Sulfurihydrogenibium yellowstonense sp. nov., an extremely thermophilic, facultatively heterotrophic, sulfur-oxidizing bacterium from Yellowstone National Park, and emended descriptions of the genus Sulfurihydrogenibium, Sulfurihydrogenibium subterraneum and Sulfurihydrogenibium azorense. Int J Syst Evol Microbiol 55 : 22632268.

10. Nazina TN, Tourova TP, et al (2001) Taxonomic study of aerobic thermophilic bacilli: descriptions of Geobacillus subterraneus gen nov., sp., nov. and Geobacillus uzenensis sp. nov. from petroleum reservoirs and transfer of Bacillus stearothermophilus, Bacillus thermocatenulatus, Bacillus thermoleovorans, Bacillus kautophilus, Bacillus thermoglucosidasius and Bacillus therdenitrificans to Geobacillus as the new combinations G. stearothermophilus, G thermocatenulatus, G.thermoleovorans, G kaustophilus, G. thermoglucosidasius and G. thermodenitrificans. Inter J Sys \& Evol Micro 51: 433-446.

11.Sokolova TG, González JM, Kostrikina NA, Chernyh NA, Slepova TV, BonchOsmolovskaya EA, Robb FT (2004) Thermosinus carboxydivorans gen. nov., sp. nov., a new anaerobic, thermophilic, carbon-monoxide-oxidizing, hydrogenogenic bacterium from a hot pool of Yellowstone National Park. Int J Syst Evol Microbiol 54:2353-2359.

12. Stöhr R, Waberski A, Liesack W, Völker H, Wehmeyer U, Thomm M (2001) Hydrogenophilus hirschii sp. nov., a novel thermophilic hydrogen-oxidizing betaproteobacterium isolated from Yellowstone National Park. Int J Syst Evol Microbiol. 51:481-488. 
13.Strobel, G.A., Dirksie, E., Sears, J., and Markworth, C. (2001) Volatile antimicrobials from a novel endophytic fungus. Microbiol. 147: 2943-2950..

14.Strobel G. (2006) Harnessing endophytes for industrial microbiology._Curr Opin Microbiol. 9: 240-4.

15. Waksman, S.A. (1967) The Actinomycetes. Ronald Press Co. New York. 
Table 1. The biological activity of M-7 VOCs against a series of fungal pathogens. The table shows the concentration of bacterial cells at the bottom of the assay tube required to bring about a $100 \%$ inhibition of the target test organism after a $48 \mathrm{hr}$ exposure to the atmosphere of the assay tube (Fig.1).

$\begin{array}{lc}\text { Fungal test organism } & \begin{array}{c}\text { Number of G. evitos cells per } \\ \text { assay tube }\end{array} \\ \text { Aspergillus fumigatus } & 1 \times 10^{7} \\ \text { Geotrichum candidum } & 5 \times 10^{7} \\ \text { Sclerotinia sclerotiorum } & 5 \times 10^{7} \\ \text { Trichoderma viride } & 2.5 \times 10^{7} \\ \text { Botrytis cinerea } & 2.5 \times 10^{7} \\ \text { Fusarium solani } & 5 \times 10^{7} \\ \text { Pythium ultimum } & 5 \times 10^{7} \\ \text { Verticillium dahliae } & 5 \times 10^{7}\end{array}$


Table 2. A GC/MS analysis of the VOCs of M-7 after 21 days incubation at $23{ }^{\circ} \mathrm{C}$ on the $\mathrm{NB}$ medium.

$\begin{array}{llll}\begin{array}{l}\text { Retention time } \\ (\mathrm{min})\end{array} & \text { Possible compound } & \begin{array}{l}\text { Relative } \\ \text { Area }\end{array} & \begin{array}{l}\text { MW } \\ \text { Daltons }\end{array} \\ 3.772 & \text { Butanal, 2-methyl-* } & 1.42 & 88.15 \\ 3.843 & \text { Butanal, 3-methyl-* } & 4.85 & 86.13 \\ 8.441 & \text { 2-Butanal, 2-methyl-* } & 0.75 & 88.15 \\ 12.224 & \text { Acetic acid* } & 4.17 & 60.05 \\ 12.346 & \text { 2-Furancarboxaldehyde* } & 0.79 & 96.09 \\ 13.215 & \text { Benzaldehyde* } & 16.29 & 106.12 \\ 13.602 & \text { Propanoic acid, 2-methyl-* } & 3.03 & 89.11 \\ 14.342 & \text { Butanoic acid* } & 3.25 & 88.11 \\ 14.450 & \text { 2(3H)-Furanone, dihydro-4- } & 1.41 & 100.23 \\ & \text { methyl- } & & \\ 14.716 & \text { Benzeneacetaldehyde* } & 6.56 & 120.15 \\ 14.839 & \text { Butanoic acid, 2-methyl-* } & 13.9 & 102.13 \\ 18.590 & \text { Phenol* } & 0.41 & 94.11 \\ 19.956 & \text { Quinoline, 3-methyl-* } & 0.33 & 143.19 \\ 20.842 & \text { Ethanone, 1-(2-aminophenyl)- } & 0.34 & 135.17\end{array}$

*Indicates that an authentic standard compound possessed the relative same retention time and mass spectrum as the compound originating with G. evitos. 
Table 3. The effects of an artificial VOC mixture of M-7 on some target assay fungi using the standard microcup assay on standard PDA plates. The assay was conducted as per Strobel et al., 2001[13] with details in the Materials and Methods section. $\mathrm{TheIC}_{50} \mathrm{~S}$ were calculated from inhibition curves generated using varying amounts of the artificial VOC mixture. The mixture was prepared using proportional amounts of authenticated compounds as in Table 2 . The test was run for $48 \mathrm{hr}$ and then measurements made.

\begin{tabular}{|c|c|c|c|}
\hline Test Organism & $\begin{array}{l}\mathrm{IC}_{50 \mathrm{~s}} \text { reported as } \\
\mu \mathrm{L} / \mathrm{mL} \text { of free air } \\
\text { space of the PDA } \\
\text { test assay plate }\end{array}$ & $\begin{array}{l}\text { Reported } \\
\text { Viability after } \\
48 \text { hrs of } \\
\text { Exposure to } \\
30 \mu \mathrm{L} \text { of } \\
\text { VOCs }\end{array}$ & $\begin{array}{l}\text { Amount Needed to } \\
\text { Yield } 100 \% \\
\text { Inhibition } \\
\quad \mu \mathrm{L}\end{array}$ \\
\hline Rhizoctonia solani & $0.052 \pm 0.007$ & Alive & 10 \\
\hline Botrytis cinerea & $0.09 \pm .002$ & Alive & 20 \\
\hline Aspergillus fumigatus & $0.067 \pm .008$ & Alive & 10 \\
\hline Fusarium solani & $0.107 \pm .0019$ & Alive & 30 \\
\hline Verticillium dahliae & $0.08 \pm .003$ & Dead & 20 \\
\hline Trichodema viride & $0.104 \pm .001$ & Alive & 10 \\
\hline Sclerotinia sclerotiorum* & $0.053 \pm .015$ & Alive & 10 \\
\hline Ceratocystis. ulmi & $0.072 \pm .008$ & Alive & 10 \\
\hline Geotrichum candidum & $0.112 \pm .003$ & Alive & 20 \\
\hline Cercospora beticola & $0.091 \pm .002$ & Alive & 10 \\
\hline Pythium ultimum & $0.102 \pm .005$ & Alive & 10 \\
\hline
\end{tabular}




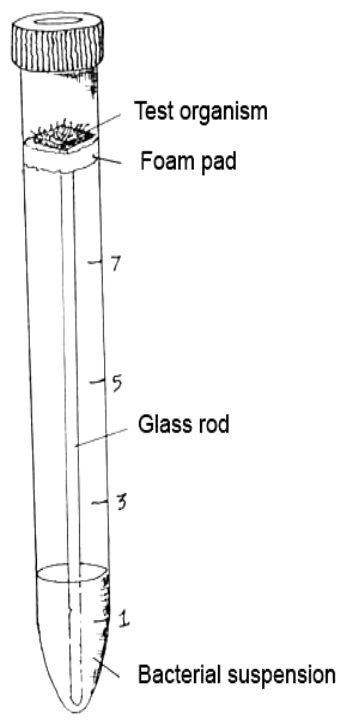

Figure 1. The system used in doing VOC inhibition assay tests using M-7 and various test organisms.

The bacterium was placed in the liquid medium at the bottom of the tube. The test organism was placed on the foam pad at the top of the tube suspended on a small glass rod. The numbers reflect the tube's capacity in $\mathrm{mL}$.

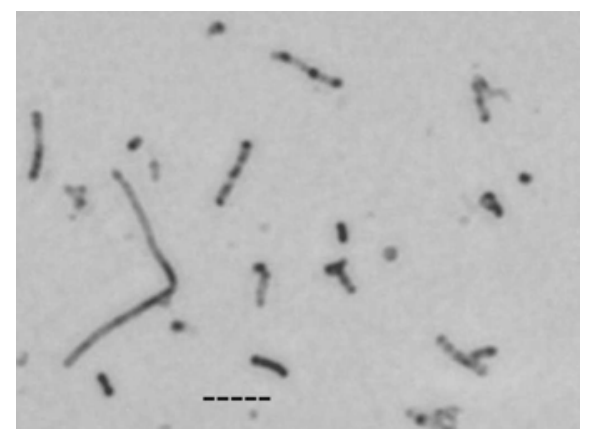

Figure 2. A Gram stained image of M-7 showing the rod-like character of the bacterium, but at the same time nicely illustrating the globose nature of the individual bacterial cells. The line is equivalent to $6 \mu$. 


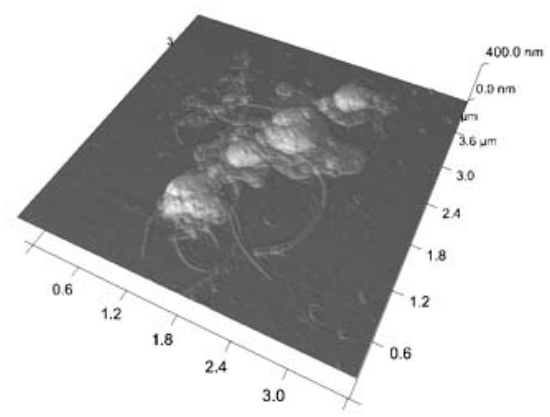

Figure 3. An AFM image of Geobacillus sp. M-7.

Note the disorganized surface of the cells represented by matrix material. The strands may represent flagellae. 
